\title{
Ranking and Selection of Strategies to Manage Services of Electricity Retail Sales
}

\author{
Ljiljana Alekseevna Sosunova ${ }^{1}$, Yulia Medvedeva ${ }^{2}$, Rafael Abdulov ${ }^{2}$, Vladimir Alekseevich Koshelev ${ }^{1} \&$ Sergey \\ Victorovich Noskov ${ }^{1}$ \\ ${ }^{1}$ Samara State University of Economics, Russia \\ ${ }^{2}$ National Research Nuclear University MEPhI, Russia \\ Correspondence: Sergey Victorovich Noskov, Samara State University of Economics, Soviet Army Street, 141, \\ Samara, 443090, Russia.
}

Received: November 1, 2014 Accepted: December 23, 2014 Online Published: March 16, 2015

doi:10.5539/ass.v11n7p215 URL: http://dx.doi.org/10.5539/ass.v11n7p215

\begin{abstract}
The target of the work is grounding, ranking and selection of strategies to manage services of electricity retailers. The analysis of the dynamics of economic indicators of the electricity supplying company and the economic and mathematical analysis of its financial multiplier to determine the influencing factors were carried out. The charts of targets and strategies to manage the services for the electricity sale to the end customers and additional services were suggested. Economic and mathematical relationships of the change in targets for the services for electricity sale and additional services from changes in the volume of attracted funds by functional management strategies were defined. A method to rank strategies to manage the services of electricity supplying companies in terms of their effectiveness was developed.
\end{abstract}

Keywords: services, electricity retail sales, economic indicators, economic and mathematical methods, objectives and strategies, financial resources, efficiency

\section{Introduction}

Currently, the Russian market of the electricity retail sales comprises of more than 1,000 guaranteeing suppliers who meet the universal service obligations, including the supply of electricity to customers (end users), and provide additional services. Guaranteeing suppliers in the market of electricity retail sales provide more than $70 \%$ of its sales to end users in European Russia and the Urals, about 50\% - to the consumers in Siberia (Analytics. Review of the Issuer, 2014; Cooke et al., 2012).

Domination of guaranteeing suppliers in regional sectors of the electricity retail market is reflected in its highly fragmented and concentrated structure. According to the conducted studies of the electricity retail market of the Volga Federal District, its structure by the concentration of sales is notable for the high values of HHI index, indicating a rather low degree of competition, especially in the Republic of Tatarstan and Bashkortostan (Grigoriev \& Shafran, 2012). Thus, among the guaranteeing suppliers in the electricity retail market of the Russian Federation, the largest volume of sales are supply companies of separate republics (up to $100 \%$ ). Apart from them, such supply companies are notable for a high proportion of electricity sales as Mosenergosbyt (83\%), Samaraenergo (79\%) and Vladimirenergosbyt (68\%) (Annual reports and financial statements, 2014; JSC "IDGC of Central and Volga Region", 2014; Disclosure. Annual Reports, 2014).

Electricity retail markets in the territorial context have a high degree of sales concentration and, consequently, a low degree of competition. This problem is not only Russian and is bound to search for the optimal combination of efficiency level either due to the economy of scale or to the degree of competition (Resolution of the Government of the Russian Federation dated 04.05.2012 No. 442; Sorokin, 2011). Restriction of competition, due to the dominance of guaranteeing suppliers in regional electricity markets, allows them to extract excess profits at the expense of the end users (organizations and people). This excess profit is then distributed through the entire chain of electricity production and supply, and its share for sales companies is negligible. In conditions of low competition and monopoly power of the guaranteeing suppliers on the electricity retail markets, the efficiency of their services to end users is reduced, the search of their innovative types is constrained, tariffs for additional services grow, and access of independent providers to the market is limited due to high transaction 
costs. All this requires to conduct the analysis of the efficiency of the electricity retailers, identify the contributing factors, set the objectives and develop strategies to manage services of electricity sales companies, as well as to select and rank the strategic solutions to achieve corporate goals, business and functional goals.

\section{Methods}

Heuristic, expert, economic and mathematical methods and models appropriate to the problems set were used at each stage of the study.

\subsection{Structure of the Study}

Structure of the study was identified by the following logical steps: selection of the research object (JSC "Samaraenergo"), analysis and evaluation of its economic and financial indicators, identification of the factors of their dynamics, formulation of problems, development of target charts and strategies to manage services of retail sales as a strategic response to the challenges, ranking and selection of the most effective strategies to manage the services.

\subsection{Representativeness of the Object of the Study}

Selection of such an electricity retailer as JSC "Samaraenergo" as an object of the study can be explained with a high proportion of its total sales in the regional sales (79.4\%), as well as the presence of similar organizations with monopoly features on other regional markets.

\subsection{Methods of Achievement and Evaluation of Intermediate and Final Outcomes of the Study}

Analysis and evaluation of economic performance and financial multiples of the company have been conducted in dynamics with the calculation of the continued growth and absolute growth for the 2009-2014 period. Economic and mathematical methods (regression analysis, estimation of the elasticity of effective features, graphical interpretation of results) and computer modeling were used. Heuristic techniques to develop target charts and business strategies of the electricity retailer and businesses to provide additional services, and methods of expert assessments to identify their consistency by the coefficients of variation were used.

\section{Outcomes}

Electricity supply to the consumers in Samara region (organizations, institutions and population) is characterized by the multi-tier nature, fragmentation of electricity retail functions, combination of the functions of the wholesale and retail trading.

Assessment of the market share of the electricity retailers in Samara region has allowed to determine the concentration of sales in the regional market and thus to establish the form of the market structure by the degree of competition. Thus, the HHI index (Herfindahl-Hirschman index) of the regional electricity retail market for the top four important retailers is currently 6428. The HHI index of the electricity retail market of Samara region indicates certain monopolistic tendencies of this market, which limits the effective competition and enables the electricity suppliers to make management decisions not in favor of consumers, including the population of the area.

The largest operator in the electricity retail market in Samara region is JSC "Samaraenergo" with a market share of 79.4\% (Annual report and financial statements, "Samaraenergo", 2014). Basic economic indicators of this company and their dynamics over the 2009-2014 period are presented in Table 1.

Thus, the electricity supply to consumers in the region (legal entities and households) has increased slightly over the period under review - from 15.3 to $16.7 \mathrm{bln}$. $\mathrm{kWh}$ or by $109.2 \%$, while proceeds from the electricity sale at current prices increased by $153.7 \%$, which is explained by the periodic revision of electricity tariffs in the direction of their increase. Company's costs of services provided to consumers (services of electricity sales and additional services) during the period under review, including their cost price, commercial and administrative expenses, grew faster than revenue (growth rate of 156.4\%), indicating the negative trend of increasing the unit cost of the sale of $1 \mathrm{kWh}$ of electricity to consumers. Growth rate of gross profit (continued) of "Samaraenergo" amounted to only $85.3 \%$ in $2011,27.4 \%$ in 2012 and $78.4 \%$ in 2013, hence its rates of growth were negative.

Indicators of the effectiveness and cost efficiency of industrial and service activities of "Samaraenergo" are generally characterized by negative values and negative dynamics. Thus, the company's net income was positive and equal to 1.18 and 0.7 RUB bln. only in 2010 and 2011, respectively; return on sales decreased from 3.55 to $1.90 \%$ over the period under review, and the return on assets - from $21.4 \%$ in 2010 to $0.34 \%$ in 2014 . All this is supported by the negative absolute growth of the sales profitability ratio and the company's assets in 2011, 2012 and 2013, but 2014 can see a small positive absolute increase expressed in percentage points, according to the estimates. 
Table 1. Basic economic indicators of "Samaraenergo"

\begin{tabular}{|c|c|c|c|c|c|c|}
\hline Indicators & 2009 & 2010 & 2011 & 2012 & 2013 & $\begin{array}{c}2014 \\
\text { (estimates) } \\
\end{array}$ \\
\hline Grid output, bln. kWh & 15.3 & 14.3 & 16.6 & 16.3 & 16.6 & 16.7 \\
\hline $\begin{array}{l}\text { Proceeds from sales of goods, products, works and } \\
\text { services, RUB bln., of which: }\end{array}$ & 27.86 & 37.96 & 37.49 & 35.87 & 40.20 & 42.83 \\
\hline - proceeds from electricity sales & 27.85 & 37.92 & 37.47 & 35.85 & 40.18 & 42.80 \\
\hline $\begin{array}{l}\text { Growth rate of proceeds from electricity sales } \\
\text { (continued), } \%\end{array}$ & - & 136.2 & 98.8 & 95.7 & 112.1 & 106.5 \\
\hline $\begin{array}{l}\text { Expenses (cost, commercial, administrative) on } \\
\text { product sales, RUB bln. }\end{array}$ & 26.87 & 35.78 & 35.63 & 35.36 & 39.80 & 42.02 \\
\hline Gross profit, RUB bln. & 0.99 & 2.18 & 1.86 & 0.51 & 0.40 & 0.78 \\
\hline Growth rates of gross profit (continued), $\%$ & - & 220.2 & 85.3 & 27.4 & 78.4 & 195.0 \\
\hline Net income RUB bln. & -1.07 & 1.18 & 0.70 & -0.24 & -0.33 & -0.20 \\
\hline $\begin{array}{l}\text { Return on sales, } \% \\
\text { Absolute increase in return on sales, percentage } \\
\text { points }\end{array}$ & $\begin{array}{c}3.55 \\
-\end{array}$ & $\begin{array}{l}5.77 \\
2.22\end{array}$ & $\begin{array}{r}4.96 \\
-0.81\end{array}$ & $\begin{array}{c}1.42 \\
-3.54\end{array}$ & $\begin{array}{r}1.00 \\
-0.42\end{array}$ & $\begin{array}{l}1.90 \\
0.90\end{array}$ \\
\hline $\begin{array}{l}\text { Return on assets, } \% \\
\text { Absolute increase in return on assets, percentage } \\
\text { points }\end{array}$ & $\begin{array}{c}-21.96 \\
-\end{array}$ & $\begin{array}{l}21.40 \\
43.36\end{array}$ & $\begin{array}{c}3.03 \\
-18.37\end{array}$ & $\begin{array}{l}-0.96 \\
-3.99\end{array}$ & $\begin{array}{l}-1.11 \\
-0.15\end{array}$ & $\begin{array}{l}0.34 \\
1.45\end{array}$ \\
\hline
\end{tabular}

The position of JSC "Samaraenergo" on the national and regional retail markets of electricity supply services can be estimated by calculating the market multiples that are used by shareholders and investors to make decisions. Major market multiples of JSC "Samaraenergo" for the 2009-2014 period are presented in Table 2.

Table 2. Market multiples of JSC "Samaraenergo"

\begin{tabular}{ccccccc}
\hline Market multiples & 2009 & 2010 & 2011 & 2012 & 2013 & 2014 (estimates) \\
\hline Market value, RUB bln. & 0.84 & 2.11 & 1.89 & 1.77 & 0.98 & 0.85 \\
Ratio of market capitalization to net earnings (P/E) & -0.71 & 1.47 & 2.20 & -6.42 & -15.66 & -21.00 \\
Ratio of market capitalization to sales (P/S) & 0.27 & 0.046 & 0.041 & 0.044 & 0.020 & 0.010 \\
Ratio of net earnings to sales (ROS), $\%$ & -3.84 & 3.12 & 1.88 & -0.13 & -0.82 & -0.47 \\
EBITDA, RUB bln. & 1.19 & 2.62 & 2.23 & 0.65 & 0.59 & 1.00 \\
Return on equity (ROE), $\%$ & -9.91 & 10.7 & 5.34 & -2.19 & -3.91 & -4.21 \\
\hline
\end{tabular}

As follows from the provided data, the market value (capitalization) of the company had the highest value of RUB 2.11 bln. in 2010, and the lowest (RUB 0.84 and $0.85 \mathrm{bln}$.) in 2009 and 2010, respectively. The ratio of market capitalization to net earnings of the company (P/E) had a positive value equal to 1.47 and 2.20 only in 2010 and 2011, respectively. The ratio of net earnings to sales (ROS) and return on equity (ROE) also were positive only in 2010 and 2011. Dynamics of other market multiples, such as the ratio of market capitalization to earnings and EBITDA as a whole is negative. Thus, the rate of P/S decreased in 2014 compared to 2010 by 4.6 times and EBITDA - by 2.62 times.

Negative dynamics of both indicators of production and service activities of the company and its market multiples requires the identification of the main causes (factors) that influenced the decline in the effectiveness and efficiency of electricity sales services provided to consumers. Methodical bases of selection of influencing factors include preliminary qualitative assessment of the reasons for the negative dynamics of the considered parameters (multipliers), which requires the establishment of causal relationships in their change.

Economic and mathematical multivariate efficiency analysis requires the establishment of effective feature as its measure and selection of factor variables of the model (Bickel et al., 2006; Li \& Wu, 2014; Ozhan et al., 2014). Productive efficiency factor of the electricity retail operation of the company may be any of the indicators of its profitability - for example, the ratio of capitalization to sales (P/S) (Financial structure and profitability of European companies, 2014; Poongavanam, 2014). Capitalization of the company as its market value at any given time is determined only as the price of its stock according to MICEX trading in rubles, and for a long period of time (mid-term and long-term) is influenced by profits and expectations of investors and shareholders. Thus, the main internal factor of the changes in capitalization is the dynamics of company profits. It must be noted that the relationship between the market capitalization of the company and its profit is not functional and deterministic, 
which allows to use mathematical and statistical methods for the analysis of stochastic relationships. In its turn, the company's profit is determined by the difference of its revenues and costs (the cost of production and sale of electricity services to consumers). Then, the causal connections, non-deterministic and stochastic, between the ratio of market capitalization to the company's revenue and influencing factors will be:

$$
\mathrm{P} / \mathrm{S} \rightarrow \frac{\text { profit }}{\text { earnings }} \rightarrow 1 . \frac{\text { cost }}{\text { earnings }} \rightarrow 1 \cdot \frac{\text { unit cost }}{\text { tariff }}
$$

Since electricity tariffs are regulated by state legislative and executive authorities, the main internal factor of the change in the $\mathrm{P} / \mathrm{S}$ market multiple is the unit cost of the company in RUB/kWh. Another factor in the changes of this market multiple that is not reflected in the scheme of the cause-effect relationships is the structure of the company's earnings, namely, the share of revenue from additional electricity services. Thus, in the multivariate analysis model of the $\mathrm{P} / \mathrm{S}$ market multiple, which is the effective sign, the factor variables may be the unit cost of the company and the share of additional services. Initial data for multivariate analysis of the ratio of capitalization to earnings of "Samaraenergo" are presented in Table 3.

Table 3. Input data for multivariate analysis of ratio of capitalization to earnings of "Samaraenergo"

\begin{tabular}{ccccccc}
\hline Indicators & 2009 & 2010 & 2011 & 2012 & 2013 & 2014 (estimates) \\
\hline Unit costs, RUB/kWh & 1.76 & 2.50 & 2.15 & 2.17 & 2.40 & 2.52 \\
Share of additional services in revenue, $\%$ & 0.036 & 0.105 & 0.053 & 0.056 & 0.050 & 0.050 \\
Ratio of market capitalization to sales (P/S) & 0.027 & 0.046 & 0.041 & 0.044 & 0.020 & 0.010 \\
\hline
\end{tabular}

Development of a multiple regression equation $(\mathrm{P} / \mathrm{S})$ from the change of unit costs of the company and share of additional services in revenue is performed in a computer program, where $\mathrm{Y}$ is the matrix of values of $\mathrm{P} / \mathrm{S}$ market multiple, $\mathrm{X}$ is the matrix of factor variables, $\mathrm{E}$ is the matrix of coefficients of multiple regression equation, $X_{1}$ is the unit cost, RUB/kWh, $X_{2}$ is the share of additional services, \% (Maxfield, 2009):

$$
Y=\left(\begin{array}{l}
0.027 \\
0.046 \\
0.041 \\
0.044 \\
0.020 \\
0.010
\end{array}\right) \quad \mathrm{X}=\left(\begin{array}{ccc}
1 & 1.76 & 0.036 \\
1 & 2.50 & 0.105 \\
1 & 2.15 & 0.053 \\
1 & 2.17 & 0.056 \\
1 & 2.40 & 0.050 \\
1 & 2.52 & 0.050
\end{array}\right) \quad \mathrm{E}=\left(\mathrm{X}^{\mathrm{T}} \cdot \mathrm{X}\right)^{-1} \cdot \mathrm{X}^{\mathrm{T}} \cdot \mathrm{Y} \quad \mathrm{E}=\left(\begin{array}{c}
0.081 \\
-0.038 \\
0.604
\end{array}\right)
$$

Consequently, the multiple regression equation is:

$$
\mathrm{Y}=0.081-0.038 \cdot \mathrm{X}_{1}+0.0604 \cdot \mathrm{X}_{2} \text {. }
$$

Coefficient of multiple determination $(\mathrm{R})$, equal to 0.68 , indicates that the change of consumption of electricity by $68.0 \%$ is determined by the factors included in the model:

$$
\mathrm{R}=\frac{\mathrm{E}^{\mathrm{T}} \cdot \mathrm{X}^{\mathrm{T}} \cdot \mathrm{Y}-6 \cdot 0.0313^{2}}{\mathrm{Y}^{\mathrm{T}} \cdot \mathrm{Y}-6 \cdot 0.0313^{2}} \quad \mathrm{R}=0.68
$$

The value of dispersion (D) of the error of economic and mathematical model of multiple regression:

$$
\mathrm{D}=\frac{\mathrm{Y}^{\mathrm{T}} \cdot \mathrm{Y}-\mathrm{E}^{\mathrm{T}} \cdot \mathrm{X}^{\mathrm{T}} \cdot \mathrm{Y}}{3} \quad \mathrm{D}=1.156 \cdot 10^{-4} .
$$

Perfect elasticity of $\mathrm{P} / \mathrm{S}$ market multiple from the changes in the unit costs of the company $\left(\mathrm{dY} / \mathrm{dX}_{1}\right)$ and the share of additional services in revenue $\left(\mathrm{dY} / \mathrm{dX}_{2}\right)$ are (Miller et al., 2012):

$$
\frac{\mathrm{dY}}{\mathrm{dX}_{1}}=-0.038\left(\frac{1}{\text { руб. } / \mathrm{\kappa BT} \cdot \mathrm{q}}\right) \quad \frac{\mathrm{dY}}{\mathrm{dX}_{2}}=0.604\left(\frac{1}{\%}\right)
$$

Thus, change of $1 \mathrm{RUB} / \mathrm{kWh}$ in the unit cost has determined the change in $\mathrm{P} / \mathrm{S}$, opposite in sign, by 0.038 , and the change in the share of additional services in the revenue by $1 \%$ has determined the change in $\mathrm{P} / \mathrm{S}$, of the same sign, by 0.604 .

The results of multivariate analysis of the change in the P/S indicator of "Samaraenergo" require the use of strategic planning as a strategic response to the negative trend of the financial multiplier based on identified factors. 
The strategic planning of the services by electricity retailers refers to one of the functions of strategic management related to the definition of objectives and the development of management strategies (Magretta, 2011). According to the order of strategic planning - in particular, goal-setting - the selected corporate purpose of the service management by "Samaraenergo" is the growth of the P/S financial multiplier.

The main target for the electricity sale services is to reduce the unit cost of $1 \mathrm{kWh}$. Changing this parameter affects the value of the company's profits, and therefore its capitalization in the numerator of the P/S financial multiplier. The value of the capitalization as the market value of the company is affected, besides its annual profits, by the external factors-risks: global, national and corporate. Thus, the global risks in the power sector are the phase of the business cycle, programs on energy conservation. The national and corporate risks of electricity retail companies include state regulation of electricity tariffs, weak growth in gross domestic product (GDP) and a decline in real income of population due to a wage freeze and high inflation.

The main target for the additional services of the company is to increase their volumes (higher share in revenues), which leads to an increase in total revenue of the electricity retail company. If the efficiency of the electricity retail company in provision of additional services grows, it means advancing the growth rate of profit from this type of activity as compared with the rate of revenue growth, which also increases profits and, consequently, capitalization in the numerator of the of the $\mathrm{P} / \mathrm{S}$ financial multiplier.

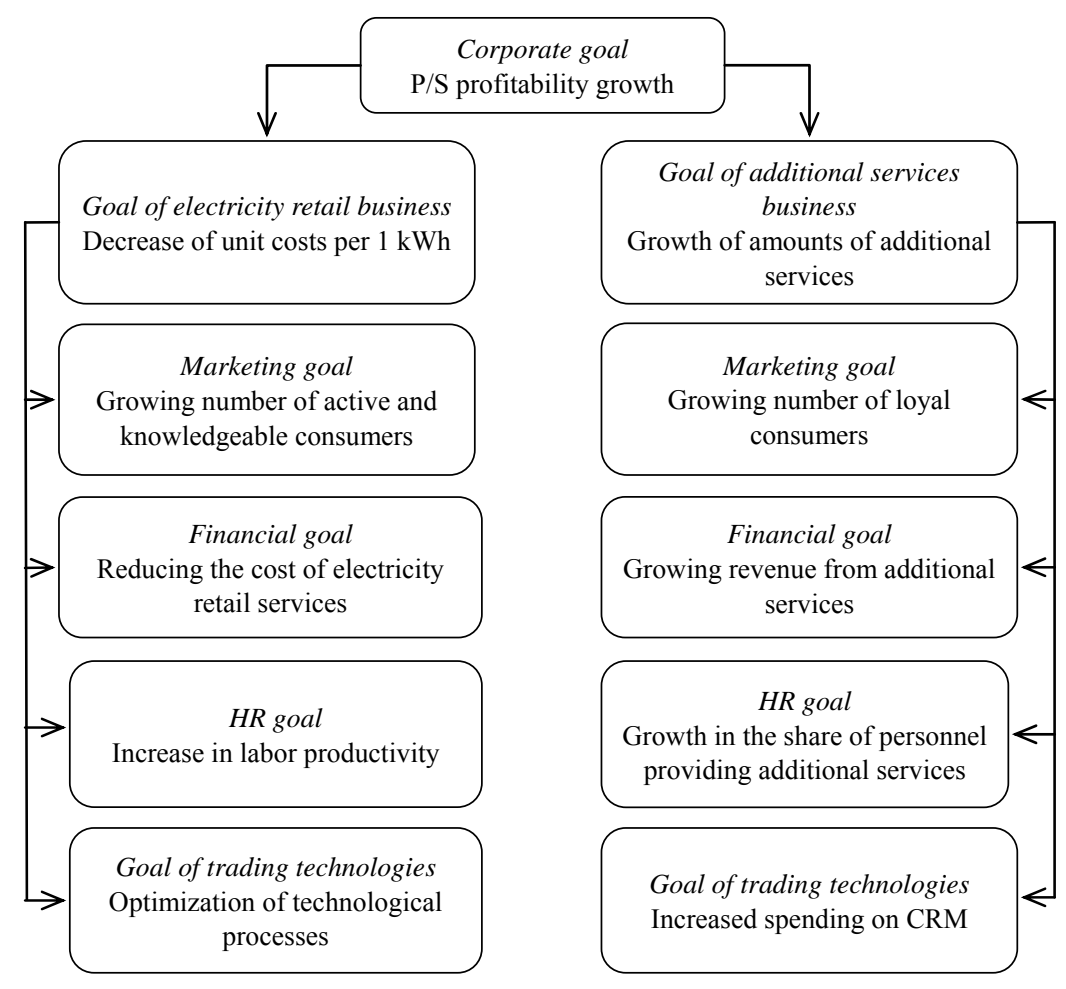

Figure 1. Hierarchy of electricity retailer's goals

The third level of decomposition of the main corporate target of the electricity retail company is its functional activity (Anshina, 2013). The following targets for the business of electricity supply to consumers can reasonably be offered for each type of functional activity:

- Marketing - increase in the number of active and knowledgeable consumers (Bushuyev et al., 2013);

- Finance - reducing the cost of services for electricity sale;

- HR management - improving the labor productivity;

- Trading technologies - optimization of technological processes.

For each type of functional activity of the business to provide additional services, the following targets are suggested:

- Marketing - increase in the number of regular customers; 
- Finance - increase in revenue from additional services;

- HR management - increase of percentage of personnel in provision of additional services;

- Trading technologies - increase in spending on customer relationship management (CRM) (Lyantsevich, 2002).

Decomposition of the corporate goal of the electricity retailer (growth of $\mathrm{P} / \mathrm{S}$ indicator) at three levels of the hierarchy (corporate, business level and functional activity) is presented in Figure 1.

The process of goal setting in the strategic planning of development of the electricity retailer's services doesn't end here, but the goal setting continues in relation to: a) functional areas of marketing, finance, human resource management and trading technologies; b) business processes (Hiriyappa, 2011; Romeo, 2014). The previously performed goal setting in respect of the electricity sale services by JSC "Samaraenergo" (business goal, marketing and financial goals, HR and trading technology goals) allows to develop the appropriate management strategies for business level and functional activities. A visual representation of the hierarchy and linkages of goals and management strategies can be implemented in the form of the chart (Norton \& Kaplan, 2007). Chart of the goals and management strategies of electricity sale services by JSC "Samaraenergo" as the core type of business is shown in Figure 2.

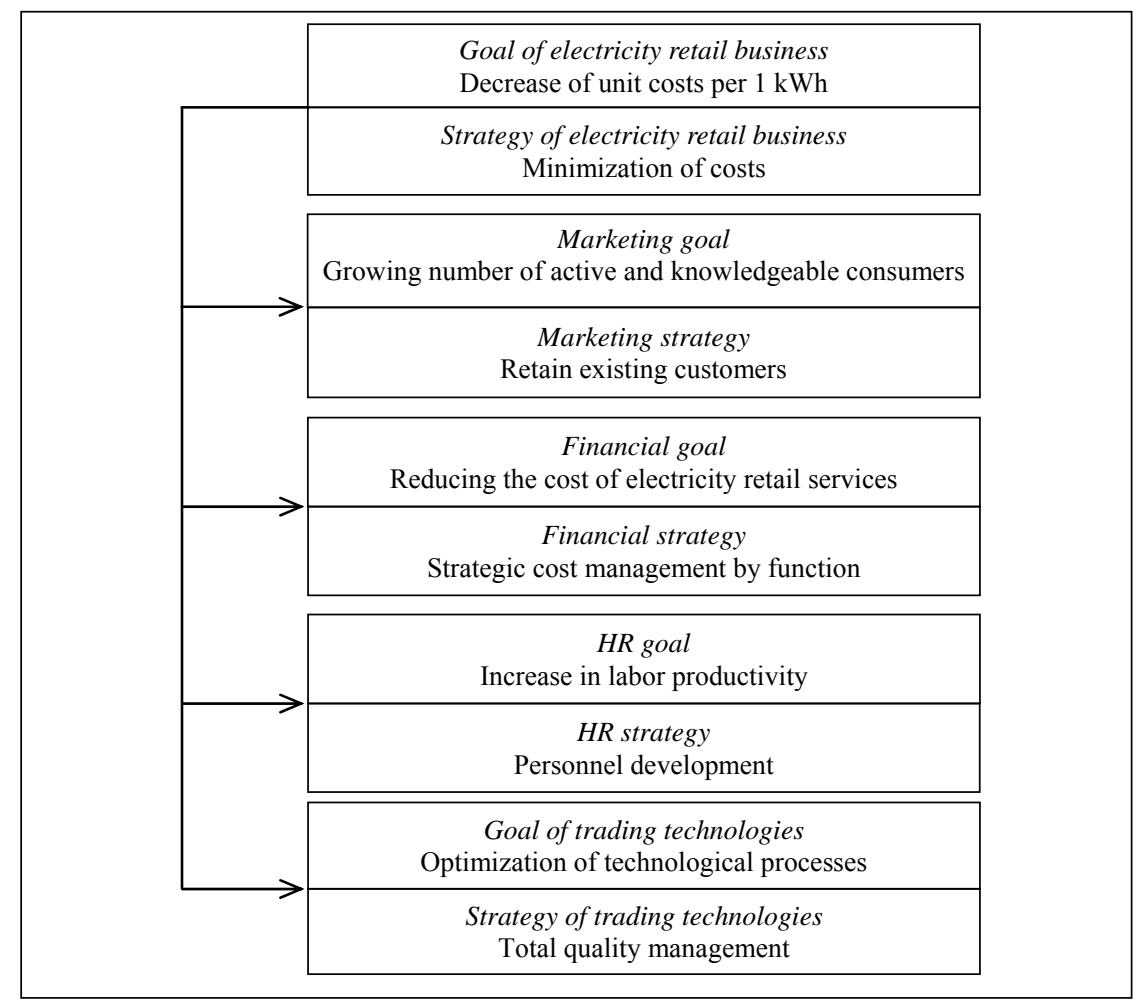

Figure 2. Chart of the goals and management strategies of electricity sale services by JSC "Samaraenergo"

According to the chart of the goals and management strategies of electricity sale services, the basic strategy of the business level is to minimize costs of the electricity retailer. Functional strategies that implement the business strategy are: retention of existing electricity consumers to maintain optimal sales (marketing strategy), strategic cost management by function and process (financial strategy), development of electricity retailer's personnel (HR strategy), total quality management (strategy of trading technologies).

The chart of the goals and management strategies of additional services by JSC "Samaraenergo" is presented in Figure 3.

Thus, the main business management strategy of additional services provided by electricity retailer is related diversification strategy, i.e. the provision of services having strategic compliance with the electricity sale to end customers (enterprises and households). The level of functional activity of the company is represented by a marketing strategy (attracting new customers), financial strategy (search for new sources of additional revenue), 
HR strategy (training of specialized personnel to provide additional services), strategy of trading technologies (technological innovation).

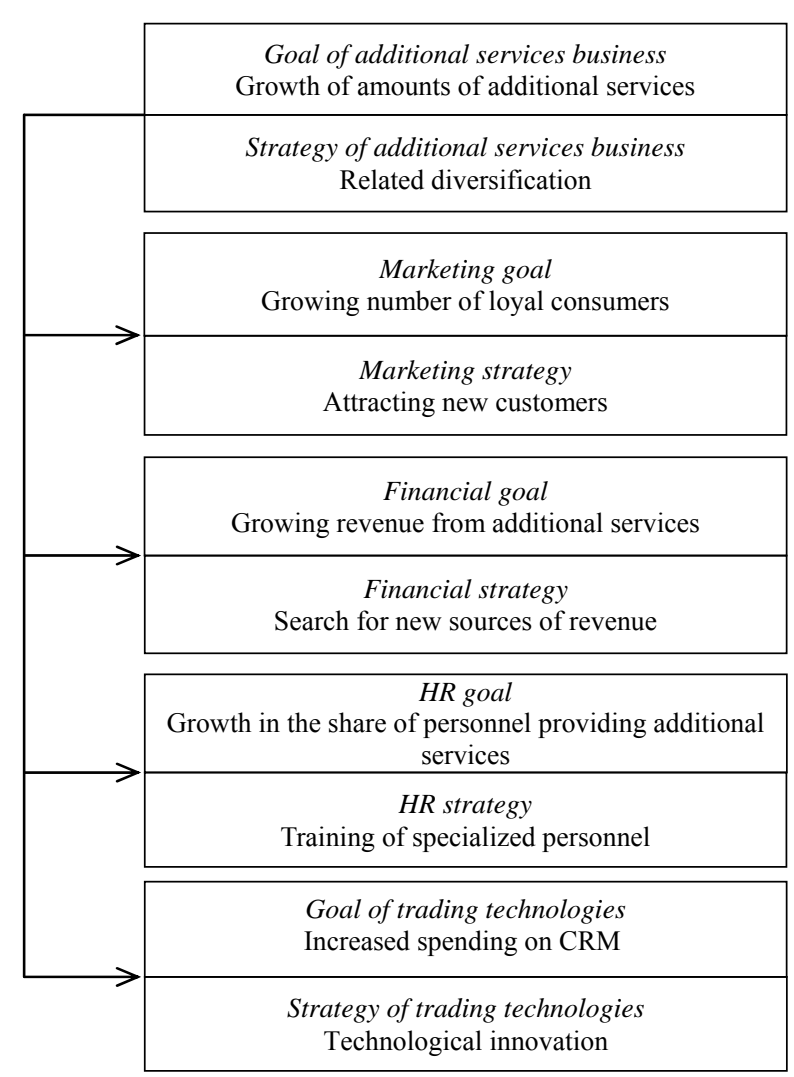

Figure 3. Chart of the goals and management strategies of additional services by JSC "Samaraenergo"

Functional strategies of management of the electricity retailer's services, from the point of view of their contribution to the achievement of the relevant business goal and implementation of business strategy, as well as resources spent, differ by parameters, which requires an assessment of each functional strategy by the level of achievement of the appropriate business goal, ranking and selection in terms of efficiency.

Ranking and selection are difficult management decisions that can be made through the use of different methods, such as intuitive, heuristic, expert assessments, economic and mathematical (Aymesheva, 2011, 2012). Selection and ranking of the service management strategies of JSC "Samaraenergo" in functional activities (marketing, finance, human resource management and trading technology) were implemented on the basis of modeling of economic and mathematical dependence from quantitative changes of the goals of this type of business from changes in the volume of the raised funds. Thus, the goal of business of the electricity retailer of electricity sale to end consumers is to reduce its costs to sell $1 \mathrm{kWh}$ of electricity as a percentage. For each volume of raised financial resources in the implementation of functional strategies to manage services of electricity retail sales, a possible reduction in the unit cost for the company was determined by expert assessments. The survey involved five specialists of electricity retailer, whose estimates were averaged. Consistency of the expert evaluations was determined by the coefficient of variation and was satisfactory, since the coefficient of variation did not exceed 0.3. These and other data, as well as the results of economic and mathematical modeling of this dependence for functional strategies to manage electricity sales services are presented in Table 4.

As follows from the provided data and the calculations, for each functional strategy to management services of JSC "Samaraenergo" for electricity sale to end customers (retention of existing customers, strategic cost management, personnel development and total quality management) there is its own economic and mathematical dependence of reduction of the company's unit costs as a percentage of volume change of the necessary financial resources in RUB mln. The charts of data regression are presented in Figure 4.

Table 4. Input data and results of economic and mathematical modeling of electricity sale services 


\begin{tabular}{|c|c|c|c|c|}
\hline \multirow{3}{*}{$\begin{array}{c}\text { Financial } \\
\text { resources, RUB } \\
\text { mln. }\end{array}$} & \multicolumn{4}{|c|}{ Possible reduction of unit costs, $\%$} \\
\hline & Marketing strategy & Financial strategy & HR strategy & $\begin{array}{l}\text { Strategy of trading } \\
\text { technologies }\end{array}$ \\
\hline & $\begin{array}{c}\text { Retain existing } \\
\text { customers }\end{array}$ & $\begin{array}{c}\text { Strategic cost } \\
\text { management }\end{array}$ & $\begin{array}{c}\text { Personnel } \\
\text { development }\end{array}$ & $\begin{array}{l}\text { Total quality } \\
\text { management }\end{array}$ \\
\hline 1 & 1 & 1 & 2 & 1 \\
\hline 5 & 2 & 4 & 5 & 4 \\
\hline 10 & 4 & 6 & 9 & 6 \\
\hline 15 & 6 & 7 & 11 & 8 \\
\hline 20 & 7 & 8 & 13 & 10 \\
\hline 25 & 8 & 9 & 14 & 11 \\
\hline 30 & 9 & 10 & 15 & 12 \\
\hline 35 & 10 & 11 & 16 & 13 \\
\hline 40 & 11 & 12 & 17 & 14 \\
\hline 45 & 12 & 13 & 18 & 15 \\
\hline Approximation & $\mathrm{y}=0.89 \cdot \mathrm{x} 0.69-0.16$ & $\mathrm{y}=2.13 \cdot \mathrm{x} 0.49-0.93$ & $\mathrm{y}=5.27 \cdot x 0.37-3.60$ & $\mathrm{y}=2.60 \cdot \mathrm{x} 0.49-1.67$ \\
\hline
\end{tabular}

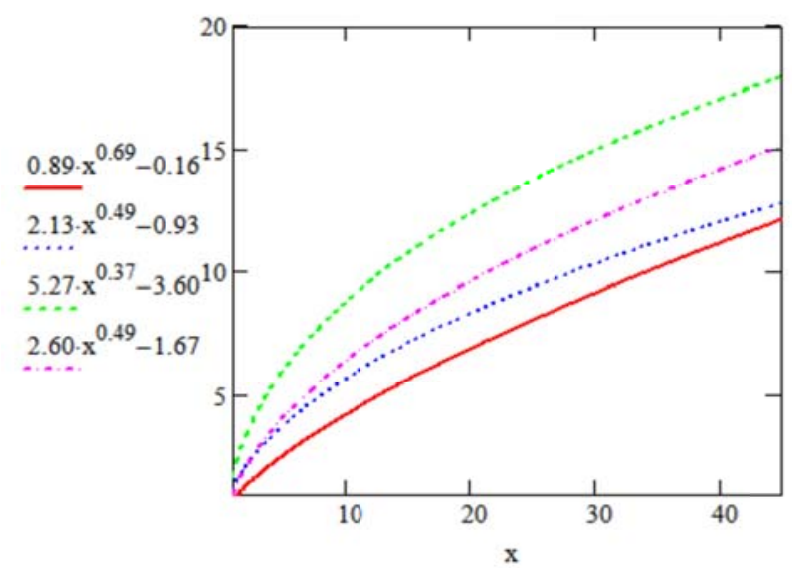

Figure 4. Regressional dependence of reduction in unit costs from changes in the volume of funds

The developed economic and mathematical relationships reflect the law of diminishing impact of financing growth of any and all functional strategies to manage services of electricity retail sales. This pattern is confirmed by the calculation of limit values of reduction of unit costs of electricity retailer as the first derivative of the regressional dependence from the changes in the volume of the necessary financial resources. For example, the increase of financial resources to the implementation of a marketing strategy - retention of existing electricity consumers by 1 RUB mln. in addition to 10 RUB mln. provides an additional $0.3 \%$ reduction in unit costs to $4 \%$, and in addition to 40 RUB mln. provides only an additional $0.2 \%$ reduction in unit costs to $11 \%$.

$$
\mathrm{y}=0.89 \cdot \mathrm{x} 0.69-0.16 \quad \frac{\mathrm{dy}}{\mathrm{d}(10)}=0.301 \quad \frac{\mathrm{dy}}{\mathrm{d}(40)}=0.196 .
$$

Or, increase of the financial resources to the implementation of HR strategy - personnel development of the electricity retailer by 1 RUB mln. in addition to 10 RUB mln. provides an additional $0.46 \%$ decline in its unit cost to $9 \%$, and to 40 RUB mln. provides only an additional $0.19 \%$ reduction in unit costs to $17 \%$.

$$
\mathrm{y}=5.27 \times \mathrm{x} 0.37-3.60 \frac{\mathrm{dy}}{\mathrm{d}(10)}=0.457 \quad \frac{\mathrm{dy}}{\mathrm{d}(40)}=0.191 .
$$

The goal of business of JSC "Samaraenergo" of provision of additional services to electricity consumers is the growth of their volumes. For each volume of financial resources raised in the implementation of functional strategies to manage the additional services by expert assessments was to determine the possibility of additional growth in volumes of services. The survey also involved five specialists of electricity retailer, whose estimates were averaged. Consistency of the expert evaluations was determined by the coefficient of variation and was satisfactory, since the coefficient of variation did not exceed 0.3 . These and other data, as well as the results of 
economic and mathematical modeling of this dependence for functional strategies to manage additional services are presented in Table 5 .

Table 5. Input data and results of economic and mathematical modeling of additional services

\begin{tabular}{ccccc}
\hline \multirow{2}{*}{$\begin{array}{c}\text { Financial } \\
\text { resources, }\end{array}$} & \multicolumn{4}{c}{ Possible growth of volumes of additional services, \% } \\
\cline { 2 - 5 } RUB mln. & Marketing strategy & Financial strategy & HR strategy & $\begin{array}{c}\text { Strategy of trading } \\
\text { technologies }\end{array}$ \\
\cline { 2 - 5 } & $\begin{array}{c}\text { Attracting new } \\
\text { customers }\end{array}$ & $\begin{array}{c}\text { Search for new } \\
\text { sources of revenue }\end{array}$ & $\begin{array}{c}\text { Training of } \\
\text { specialized personnel }\end{array}$ & $\begin{array}{c}\text { Technological } \\
\text { innovation }\end{array}$ \\
\hline 2 & 3 & 2 & 1 & 2 \\
4 & 8 & 6 & 7 & 7 \\
6 & 13 & 10 & 13 & 12 \\
8 & 17 & 13 & 18 & 17 \\
10 & 20 & 15 & 23 & 21 \\
12 & 22 & 17 & 27 & 25 \\
14 & 23 & 19 & 30 & 32 \\
16 & 25 & 20 & 32 & 34 \\
18 & 26 & 22 & 33 & 35 \\
20 & 27 & $\mathrm{y}=25.0 \cdot \mathrm{x} 0.23-27.78$ & $\mathrm{y}=26.5 \cdot \mathrm{x} 0.32-33.03$ & $\mathrm{y}=9.9 \cdot \mathrm{x} 0.54-13.15$ \\
\hline
\end{tabular}

The charts of regressional dependence of growth in volumes of additional services of electricity retailer as a percentage from changes in the volume of raised financial resources in the implementation of functional strategies to manage additional services are presented in Figure 5.

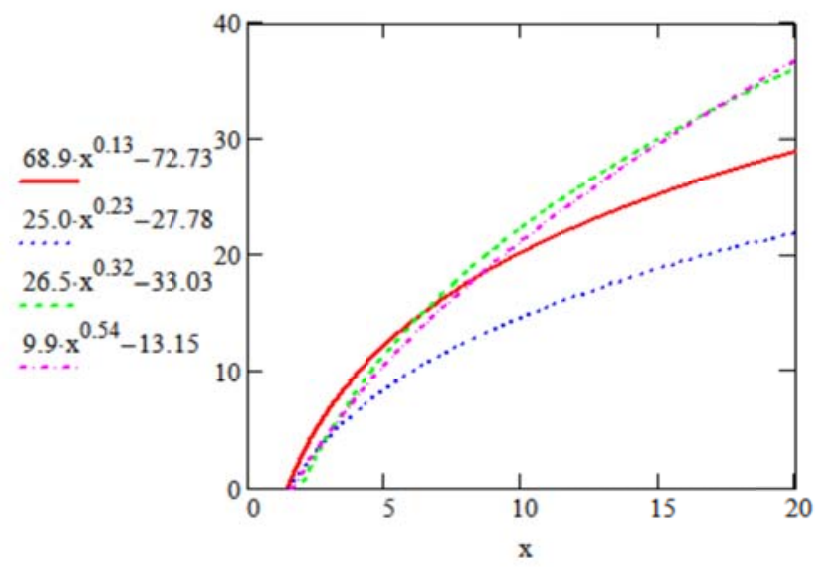

Figure 5. Regressional dependence of growth in volumes of additional services from changes in the volume funds

The results of economic and mathematical modeling of dependence of growth in volumes of additional services of electricity retailer are also characterized by the decreasing effectiveness of increasing the volumes of financial resources to the implementation of functional management strategies. For example, an increase in funds to the implementation of the marketing strategy to attract new consumers of electricity retailer by 1 RUB mln. in addition to 10 RUB mln. provides an additional $1.21 \%$ growth in value-added services to $20 \%$, and to 20 RUB mln. provides an additional $0.36 \%$ the growth of additional services to $27 \%$ :

$$
\mathrm{y}=68.9 \cdot \mathrm{x} 0.13-72.736 \quad \frac{\mathrm{dy}}{\mathrm{d}(10)}=1.208 \quad \frac{\mathrm{dy}}{\mathrm{d}(20)}=0.362 .
$$

Assessment of the effectiveness of each of the functional strategies to manage services of electricity sale to end customers of JSC "Samaraenergo" is performed by an indicator that is characterized by the ratio of the effectiveness of functional strategies to manage the electricity sale services (reduction of unit costs) and functional strategies to manage additional services (growth in their volume) to raised funds. 
Charts of the effectiveness of each functional strategy to manage services of electricity sale to end customers are presented in Figure 6.

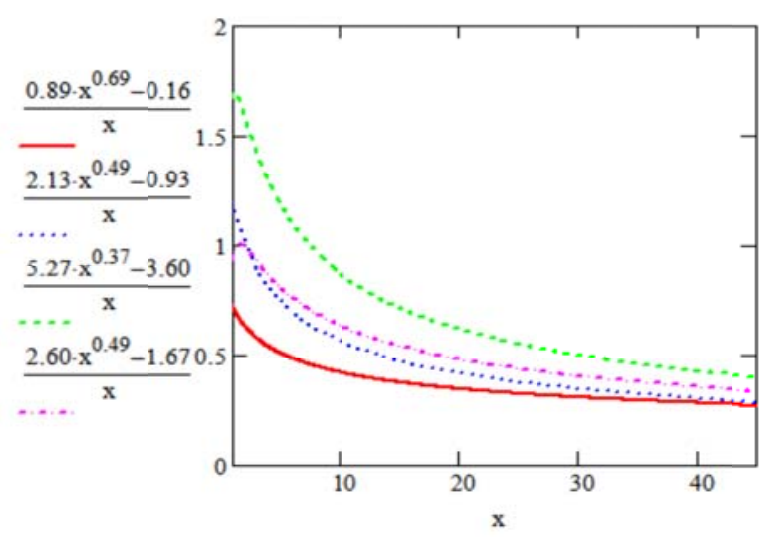

Figure 6. Effectiveness of strategies to manage electricity sale services

As follows from the developed charts, the most effective strategy to manage electricity sale services that implements the business goal of "Samaraenergo" as the reduction of unit costs of the company is the HR strategy (developing personnel qualifications), and the least effective is marketing strategy (retain existing customers).

Charts of the effectiveness of each functional management strategy to manage additional services of JSC "Samaraenergo" are presented in Figure 7.

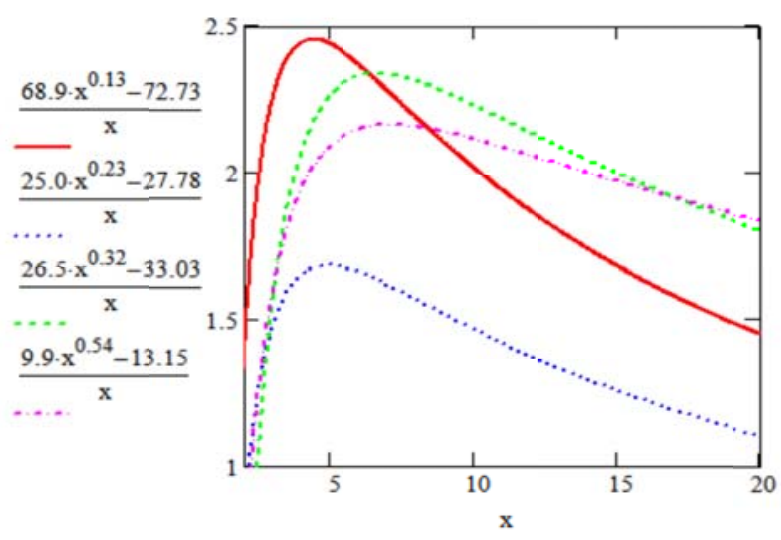

Figure 7. Effectiveness of strategies to manage additional services

As follows from the provided charts, the most effective strategies to manage the additional services that implement the business goal of JSC "Samaraenergo" is a marketing strategy - to attract new customers at a cost of financial resources under 6.411 RUB mln., HR strategy - training of specialized personnel to provide additional services at a cost of financial resources from 6.411 to 17.073 RUB mln., strategy of trading technologies - technological innovation at a cost of financial resources over 17.073 RUB mln. These calculations in the computer program are as follows:

$$
\begin{array}{lll}
f(x)=\frac{68.9 \cdot x^{0.13}-72.73}{x}-\frac{26.5 \cdot x^{0.32}-33.03}{x} & \text { solution }=\operatorname{root}(f(x), x) & \text { solution=6.411 } \\
f(x)=\frac{26.5 \cdot x^{0.32}-33.03}{x}-\frac{9.9 \cdot x^{0.54}-13.15}{x} & \text { solution }=\operatorname{root}(f(x), x) & \text { solution }=17.073 .
\end{array}
$$

The least effective strategy to manage additional services is a financial strategy - the search for new sources of revenue. 


\section{Discussions}

A number of hypotheses were put forward in this study, different research methods were used, and the results were derived on their base that may be the subject of discussion.

Firstly, the definition of objectives and rationale for strategies to manage the electricity retailer's services are heuristic process that allows to justify another indicator of profitability of the company as its corporate goal - for example, the indicator of return on assets is most often used. Goals and strategies of the functional activities of the company can be supplemented by goals and strategies of logistics, for example. Secondly, the method of expert estimations, which is used to obtain baseline data on the possible reduction of unit costs of the company and a possible increase in the volume of additional services at different amounts of financial resources, requires highly skilled professionals of electricity retailers. The most highly qualified specialists are usually employed by the leading and largest electricity retailers. Thirdly, economic and mathematical modeling used in this study is based on near-minimum number of observations to identify the dependences obtained.

Also the significance of the study results to other electricity retailers may be the subject of discussion. The results of the study are relevant for the leading regional electricity retailers with high market share (Mosenergosbyt, Vladimirenergosbyt, Nizhnovenergosbyt, Chelyabenergosbyt, Lenenergo and others). Small electricity retailers and those that only enter the market can set different goals and develop different strategies to control other services.

\section{Conclusions}

Further study could be directed at optimizing the allocation of financial resources across the individual management strategies according to the criteria of maximum reduction of unit costs and the growth of additional services. The obtained results of optimal allocation of resources are the basis for a strategic plan of activities and projects that implement management strategies at the allocated optimal levels of financial resources. Further procedures of strategic planning of services of electricity sale and additional services are related to the monitoring of the implementation of the strategic plan and its control with feedback.

\section{References}

Analytics. Review of the Issuer. 20.12.12. Russian power sector: Does it have a place for private investors? Aton Group. (2014). Retrieved May 27, 2014, from http://www.aton-line.ru/analytics/recommendations/ company/

Annual report for 2013. JSC "IDGC of Central and Volga Region". "Vladimirenergo" branch. (2014, June 30). JSC "Interregional Distribution Grid Company of Central and Volga Region”. Retrieved July 21, 2014, from http://www.mrsk-cp.ru/?id=72184

Annual reports and financial statements. (2014, October 5). Samaraenergo. Retrieved July 21, 2014, from http://www.samaraenergo.ru/stockholder/report/

Anshina, M. (2013). Objectives of the IT department. Desktop magazine of IT CIO “The Director”, 3. Retrieved February 13, 2014, from http://www.osp.ru/cio/2013/03/13034659/

Aymesheva, J. S. (2011). Systematics of infrastructure services in the electricity industry. AlPari, 1(65), 156-159.

Aymesheva, J. S. (2012). Methods of decision-making in the electricity industry. AlPari, 1(199), 149-155.

Bickel, P. J., \& Doksum, K. A. (2006). Mathematical Statistics, Basic Ideas and Selected Topics (2nd ed., Vol. 1, p. 576). Pearson.

Bushuyev, V., Kobets, B., Lizalek, N., \& Vasiliev, V. (2013). Energy policy. Smart electricity development involving an "active" user (p. 84). Energy.

Cooke, D., Antonyuk, A., \& Murray, I. (2012). Toward a More Efficient and Innovative Electricity Sector in Russia. Consultation Paper. International Energy Agency. http://dx.doi.org/10.1787/5k9cv8g6k1bx-en

Disclosure. Annual reports. "Mosenergosbyt". (2014, October 5). Retrieved October 18, 2014, from http://www.mosenergosbyt.ru/portal/pls/portal/docs/1/2126590.PDF.

Financial structure and profitability of European companies. (2014). BACH Outlook \#2. Retrieved from http://www.bach.banque-france.fr/?lang=en

Grigoriev, A., \& Shafran, A. (2012). Electricity industry today: competition without competitors? ANO "Institute of Natural Monopolies (IPEM)". Retrieved December 5, 2014, from http://www.ipem.ru/news/publications/ $556 . \mathrm{html}$ 
Hiriyappa, B. (2011). Strategic Planning (p. 70). CreateSpace.

Li, L., \& Wu, S. (2014). "A study on dynamic evaluation and comparison of regional economic synergistic development in China based on Data Envelopment Analysis". Journal of East China Economic Management, 28, 65-69.

Lyantsevich, M. (2002). Development of CRM strategy: in search of the essence of managing customer relationships. Corporate Management. Retrieved December 15, 2014, from http://www.cfin.ru/itm/ crm_strategy.shtml

Magretta, J. (2011). Understanding Michael Porter: The Essential Guide to Competition and Strategy Hardcover (1st ed., p. 256). Harvard Business Review Press.

Maxfield, B. (2009). Essential Mathcad for Engineering, Science, and Math, Second Edition (2nd ed., p. 501). Academic Press.

Miller, I., Miller, M., \& John, E. (2012). Freund's Mathematical Statistics with Applications (8th ed., p. 544). Pearson.

Norton, D., \& Kaplan, R. (2007). Strategy charts. Transformation of the intangible assets into tangible outcomes (p. 512). CJSC Olympus-Business.

Ozhan, K., Saeidi, M., \& Saeidi, H. (n. d.). Investigation of Efficient Key Factors on Kaizen Management System in Planning unit of PARS KHODRO COMPANY (Case study: NISSAN CO.), 2(7), 3007-3021. http://dx.doi.org/14.9831/1444-8939.2014/2-7/MAGNT.125

Poongavanam, S. (2014). A Study on Liquidity and Profitability Position with Reference to Sponge Iron India Limited. International Journal of Applied Engineering Research, 9(12), 1807-1824.

Resolution of the Government of the Russian Federation "On the functioning of retail electricity markets, complete and (or) partial restriction mode of electric power consumption" of 04.05.2012 \#442.

Romeo, S. (2014). Strategic Planning (p. 147). Kindle.

Sorokin, V. P. (2011). Regulatory issues of energy strategy and policy of the European Union up to 2020 (p. 34). Book on Demand.

\section{Copyrights}

Copyright for this article is retained by the author(s), with first publication rights granted to the journal.

This is an open-access article distributed under the terms and conditions of the Creative Commons Attribution license (http://creativecommons.org/licenses/by/3.0/). 